\title{
Eco-friendly synthesis and antimicrobial activities of some 1-phenyl-3(5-bromothiophen-2-yl)-5- (substituted phenyl)-2-pyrazolines
}

Ramalingam Sasikala, Kannan Thirumurthy, Perumal Mayavel and Ganesamoorthy Thirunarayanan*

\begin{abstract}
Background: Green catalyst fly ash: $\mathrm{H}_{2} \mathrm{SO}_{4}$ was prepared by mixing fly ash and sulphuric acid. Microwave irradiations are applied for solid phase cyclization of 5-bromo-2-thienyl chalcones and phenyl hydrazine hydrate in the presence of fly ash: $\mathrm{H}_{2} \mathrm{SO}_{4}$ yields, 1-phenyl-3(5-bromothiophen-2-yl)-5-(substituted phenyl)-2-pyrazolines. These pyrazolines were characterized by their physical constants and spectral data. The antimicrobial activities of all synthesized pyrazolines have been studied.

Results: Scanning electron microscopy (SEM) analysis shows the morphology changes between fly ash and the catalyst fly ash: $\mathrm{H}_{2} \mathrm{SO}_{4}$. The SEM photographs with the scale of 1 and $50 \mu \mathrm{m}$ show the fly-ash particle is corroded by $\mathrm{H}_{2} \mathrm{SO}_{4}$ (indicated by arrow mark), and this may be due to dissolution of fly ash by $\mathrm{H}_{2} \mathrm{SO}_{4}$. The yields of 1-phenyl-3 (5-bromothiophen-2-yl)-5-(substituted phenyl)-2-pyrazolines is more than $75 \%$ using this catalyst under microwave heating. All pyrazolines showed moderate activities against antimicrobial strains.

Conclusion: We have developed an efficient catalytic method for synthesis of 1-phenyl-3(5-bromothiophen-2-yl)-5(substituted phenyl)-2-pyrazolines by solid phase cyclization using a solvent-free environmentally greener catalyst fly ash: $\mathrm{H}_{2} \mathrm{SO}_{4}$ under microwave irradiation between aryl chalcones and hydrazine hydrate. This reaction protocol offers a simple, economical, environment friendly, non-hazardous, easier work-up procedure, and good yields. All synthesized pyrazoline derivatives showed moderate antimicrobial activities against bacterial and fungal strains.
\end{abstract}

Keywords: 1-phenyl-3(5-bromothiophen-2-yl)-5-(substituted phenyl)-2-pyrazolines, Fly ash: $\mathrm{H}_{2} \mathrm{SO}_{4}$, Environmentally benign reaction, IR and NMR spectra, Antimicrobial activities

\section{Background}

Pyrazolines are well-known important nitrogen containing five membered heterocyclic bioorganic molecules. The pyrazoline ring protons were bonded with carbon atoms on a spatially different environment. These pyrazolines are used widely in the current decades due to their various biological and pharmacological activities [1]. The $\alpha, \beta$-unsaturated ketones can play the role of versatile precursors in the synthesis of the corresponding pyrazolines [2-7]. Numerous methods have been reported for the preparation of pyrazoline compounds. Fischer and Knoevenagel in the nineteenth century studied the reaction of $\alpha, \beta$-unsaturated aldehydes and

\footnotetext{
* Correspondence: drgtnarayanan@gmail.com

Department of Chemistry, Annamalai University, Annamalai Nagar 608 002,
} India ing, which became one of the most popular methods for the preparation of 2-pyrazolines [8]. In 1998, Powers et al. [9] have reported the reaction of chalcones with phenyl hydrazine hydrochloride in the presence of sodium hydroxide and absolute ethanol at $70^{\circ} \mathrm{C}$, where the longer reaction time is the disadvantage of the reaction. $\mathrm{K}_{2} \mathrm{CO}_{3}$-mediated microwave irradiation has been shown to be an efficient method for the synthesis of pyrazolines [10]. The regioselective formation of pyrazolines has been synthesized by the reaction of substituted hydrazine with $\alpha, \beta$-unsaturated ketones $[11,12]$. Recently, many organic reactions in aqueous media have been described in the literature [13]. In 2007, $\mathrm{Li}$ et al. [14] have synthesized 1,3,5-triaryl-2-pyrazoline with chalcones and phenyl hydrazine hydrochloride in sodium acetate-acetic acid aqueous solution under ultrasound 
irradiation. Pyrazolines have been exhibiting various pharmacological activities, such as analgesic [15], antiinflammatory [16,17], antimicrobial [18,19], anti-amoebic $[20,21]$, antitubercular [22,23], hypoglycemic [24], anticoagulant [25], antidepressant [26-28], pesticide [29], fungicide [30], antibacterial [31], and anticonvulsant activities [32]. Recent report shows some new pyrazolinesubstituted thiazolone-based compounds that exhibit anticancer activity [33]. Apart from biological activities, pyrazolines are also extensively used as synthons in organic synthesis [34-36], as optical brightening agents for textiles, paper, and fabrics, and as a hole-conveying medium in photoconductive materials [37-41]. In this present study, the authors have taken efforts to synthesize a series of 1-phenyl-3(5-bromothiophen-2-yl)5-(substituted phenyl)-2-pyrazolines from 5-bromo-2thienyl chalcones and phenyl hydrazine hydrate in presence of fly ash: $\mathrm{H}_{2} \mathrm{SO}_{4}$. These pyrazolines were characterized by their physical constants and spectral data. The antimicrobial activities of all synthesized pyrazolines have been studied.

\section{Methods}

\section{Materials}

All chemicals used were purchased from Sigma-Aldrich Corporation (St. Louis, MO, USA) and E-Merck chemical company (Merck Limited, Mumbai, India) Melting points of all pyrazolines have been determined in open glass capillaries on Mettler FP51 melting point apparatus (Mettler-Toledo India Private Limited, Mumbai, India) and are uncorrected. Infrared spectra $(\mathrm{KBr}, 4,000$ to $400 \mathrm{~cm}^{-1}$ ) have been recorded on AVATAR-300 Fourier transform spectrophotometer (Thermo Nicolet, USA). A BRUKER AMX-500 NMR spectrometer (BRUKER AXS GMBH, Karlsruhe, Germany) operating at $500 \mathrm{MHz}$ has been utilized for recording ${ }^{1} \mathrm{H}$ spectra and $125.75 \mathrm{MHz}$ for ${ }^{13} \mathrm{C}$ spectra in $\mathrm{CDCl}_{3}$ solvent using TMS as internal standard. Electron impact $(70 \mathrm{eV})$ and chemical ionization mode $\mathrm{FAB}^{+}$mass spectra have been recorded in VARIAN-SATURN 2200 GC-MS spectrometer (Varian Medical Systems, Palo Alto, CA, USA).

\section{Results and discussion}

Fly ash is a waste air pollutant, and it has many chemical species [10,33], such as $\mathrm{SiO}_{2}, \mathrm{Fe}_{2} \mathrm{O}_{3}, \mathrm{Al}_{2} \mathrm{O}_{3}, \mathrm{CaO}$, and $\mathrm{MgO}$, and insoluble residues. The waste fly ash is converted into useful catalyst fly ash: $\mathrm{H}_{2} \mathrm{SO}_{4}$ by mixing fly ash and sulphuric acid. The sulphuric acid-sulphate ion group and chemical species present in the fly ash have enhanced catalytic activity. During the course of the reactions, these species are responsible for the promoting effects on cyclization between the chalcones and hydrazine hydrate leading to the formation of pyrazolines. In these experiments, the products were isolated, and the catalyst was washed with ethyl acetate, heated to $100^{\circ} \mathrm{C}$, and was then reusable for further five run reactions. There was no appreciable change in the percentage of yield of pyrazolines. In this protocol, the reaction gave better yields of the pyrazolines during the condensation without any environmental discharge. The analytical and mass spectral data are presented in Table 1. The infrared (IR) and nuclear magnetic resonance (NMR) spectral data of unknown pyrazolines are presented in Tables 2, and 3 .

\section{Infrared spectral study}

In the IR spectra of synthesized pyrazolines, the stretching frequency at 1,593 to $1,596 \mathrm{~cm}^{-1}$ is assigned to $\mathrm{C}=\mathrm{N}$. The frequency at 678 to $688 \mathrm{~cm}^{-1}$ is due to the C-S group, and a band at 531 to $569 \mathrm{~cm}^{-1}$ is assigned to the $\mathrm{C}$-Br stretching frequency. A collection of medium bands observed in the region 3,028 to $2,854 \mathrm{~cm}^{-1}$ is attributed

Table 1 Analytical and mass spectral data of 1-phenyl-3(5-bromothiophen-2-yl)-5-(substituted phenyl)-2-pyrazolines

\begin{tabular}{|c|c|c|c|c|c|c|}
\hline Entry & Substituent & MF & $\begin{array}{l}\text { FW } \\
\text { (dalton) }\end{array}$ & $\begin{array}{l}\text { Yield } \\
(\%)\end{array}$ & M.p. $\left({ }^{\circ} \mathrm{C}\right)$ & Mass $(\mathrm{m} / \mathrm{z})$ \\
\hline 1 & $\mathrm{H}$ & $\mathrm{C}_{20} \mathrm{H}_{17} \mathrm{BrN}_{2}$ & 365 & 85 & $152-153$ & $365\left[\mathrm{M}^{+}\right], 367\left[\mathrm{M}^{+2}\right], 287,285,221,209,142,79,77,68,65,41,28,14$ \\
\hline 2 & $4-\mathrm{Br}$ & $\mathrm{C}_{20} \mathrm{H}_{16} \mathrm{Br}_{2} \mathrm{~N}_{2}$ & 444 & 83 & $148-150$ & $\begin{array}{l}444\left[\mathrm{M}^{+}\right], 446\left[\mathrm{M}^{+2}\right], 448\left[\mathrm{M}^{+4}\right], 365,363,229,222,201,155,142,77 \\
68,41,28,14\end{array}$ \\
\hline 3 & $2-\mathrm{Cl}$ & $\mathrm{C}_{20} \mathrm{H}_{17} \mathrm{BrClN}_{2}$ & 399 & 75 & $142-144$ & $\begin{array}{l}399\left[\mathrm{M}^{+}\right], 401\left[\mathrm{M}^{+2}\right], 403\left[\mathrm{M}^{+4}\right], 363,321,319,287,225,209,142,111 \\
77,68,65,41,28,35,14\end{array}$ \\
\hline 4 & $4-\mathrm{Cl}$ & $\mathrm{C}_{20} \mathrm{H}_{17} \mathrm{BrClN}_{2}$ & 399 & 79 & 147-149 & $\begin{array}{l}399\left[\mathrm{M}^{+}\right], 401\left[\mathrm{M}^{+2}\right], 403\left[\mathrm{M}^{+4}\right], 363,321,287,225,209,14277,65 \\
41,28,14\end{array}$ \\
\hline 5 & $3,4-\left(\mathrm{OCH}_{3}\right)_{2}$ & $\mathrm{C}_{22} \mathrm{H}_{21} \mathrm{BrN}_{2} \mathrm{O}_{2}$ & 425 & 85 & $140-142$ & $\begin{array}{l}425\left[\mathrm{M}^{+}\right], 427\left[\mathrm{M}^{+2}\right], 393,363,347,287,251,142,134,107,95,78,65 \\
41,28,14\end{array}$ \\
\hline 6 & - I & $\mathrm{C}_{20} \mathrm{H}_{17} \mathrm{BrlN}_{2}$ & 491 & 76 & 146-148 & $\begin{array}{l}491\left[\mathrm{M}^{+}\right], 493\left[\mathrm{M}^{+2}\right], 495\left[\mathrm{M}^{+4}\right], 412,363,347,287,269,229,203,142 \\
126,77,42,28,14\end{array}$ \\
\hline 7 & 4- $\left(\mathrm{OCH}_{3}\right)$ & $\mathrm{C}_{21} \mathrm{H}_{19} \mathrm{BrN}_{2} \mathrm{O}$ & 395 & 85 & $128-130$ & $395\left[\mathrm{M}^{+}\right], 397\left[\mathrm{M}^{+2}\right], 363,317,287,210,142,105,77,41,14$ \\
\hline 8 & $4-\mathrm{CH}_{3}$ & $\mathrm{C}_{21} \mathrm{H}_{19} \mathrm{BrN}_{2}$ & 379 & 83 & $148-149$ & $379\left[\mathrm{M}^{+}\right], 381\left[\mathrm{M}^{+2}\right], 365,287,235,210,142,91,77,41,14$ \\
\hline
\end{tabular}

FW, formula weight; $M F$, molecular formula; M.p., melting point; $\mathrm{m} / \mathrm{z}$, mass-to-change ratio. 
Table 2 IR and NMR spectral data of 1-phenyl-3(5-bromothiophen-2-yl)-5-(substituted phenyl)-2-pyrazolines

\begin{tabular}{|c|c|c|c|c|c|c|c|c|c|c|c|c|c|c|c|c|c|c|}
\hline \multirow{2}{*}{\multicolumn{2}{|c|}{ Entry $\mathrm{X}$}} & \multicolumn{5}{|c|}{ Infrared bands $\left(\mathrm{v} \mathrm{cm}^{-1}\right)$} & \multicolumn{5}{|c|}{${ }^{1} \mathrm{H}$ chemical shifts $\delta$ (ppm) } & \multirow{2}{*}{\multicolumn{2}{|c|}{ Entry $\mathrm{X}$}} & \multicolumn{5}{|c|}{${ }^{13} \mathrm{C}$ chemical shifts $\delta$ (ppm) } \\
\hline & & $\mathrm{C}=\mathrm{N}$ & C-S & C-Br & Ar-C and Alip-C & Subst. & $\mathrm{Ha}(1 \mathrm{H}, d d)$ & $\mathrm{Hb}(1 \mathrm{H}, d d)$ & $\mathrm{Hc}(1 \mathrm{H}, d d)$ & Ar-H & Subst. & & & $\overline{C_{3}}$ & $\mathrm{C}_{4}$ & $C_{5}$ & Ar-C & Subst. \\
\hline \multirow[t]{2}{*}{1} & $\mathrm{H}$ & 1,593 & 679 & 562 & $3028-2854$ & - & 3.06 & 3.77 & 5.25 & $6.71-7.34$ & - & 1 & $\mathrm{H}$ & 155.60 & 43.66 & 64.68 & $111.77-146.521$ & - \\
\hline & & & & & & & $J=24 \mathrm{~Hz}$ & $J=29 \mathrm{~Hz}$ & $J=19 \mathrm{~Hz}$ & $(12 \mathrm{H}, \mathrm{m})$ & & & & & & & & \\
\hline \multirow[t]{2}{*}{2} & $4-B r$ & 1,596 & 685 & 5,621 & $3089-2852$ & - & 3.07 & 3.82 & 5.26 & $6.70-7.51$ & - & 2 & $4-B r$ & 155.56 & 43.45 & 64.10 & $112.13-144.13$ & - \\
\hline & & & & & & & $J=30 \mathrm{~Hz}$ & $J=28 \mathrm{~Hz}$ & $J=24 \mathrm{~Hz}$ & $(11 \mathrm{H}, \mathrm{m})$ & & & & & & & & \\
\hline \multirow[t]{2}{*}{3} & $2-\mathrm{Cl}$ & 1,595 & 690 & 566 & $3065-2852$ & - & 3.01 & 3.93 & 5.66 & $6.77-7.48$ & - & 3 & $2-\mathrm{Cl}$ & 157.50 & 42.08 & 61.50 & $113.28-143.99$ & - \\
\hline & & & & & & & $J=23 \mathrm{~Hz}$ & $J=29 \mathrm{~Hz}$ & $J=19 \mathrm{~Hz}$ & $(11 \mathrm{H}, \mathrm{m})$ & & & & & & & & \\
\hline \multirow[t]{2}{*}{4} & $4-\mathrm{Cl}$ & 1,594 & 688 & 5,31 & $3046-2852$ & - & 3.10 & 3.80 & 5.28 & $6.75-7.35$ & - & 4 & $4-\mathrm{Cl}$ & 155.82 & 43.70 & 64.75 & $113.52-144.40$ & - \\
\hline & & & & & & & $J=24 \mathrm{~Hz}$ & $J=29 \mathrm{~Hz}$ & $J=19 \mathrm{~Hz}$ & $(11 \mathrm{H}, \mathrm{m})$ & & & & & & & & \\
\hline \multirow[t]{2}{*}{5} & $3,4-\left(\mathrm{OCH}_{3}\right)_{2}$ & 1,594 & 678 & 569 & $3073-2873$ & 1,254 & 3.08 & 3.76 & 5.17 & $6.75-7.36$ & $3.83,3.87$ & 5 & $3,4-\left(\mathrm{OCH}_{3}\right)_{2}$ & 155.63 & 43.81 & 64.89 & $111.68-149.74$ & $55.94,55.98$ \\
\hline & & & & & & & $J=25 \mathrm{~Hz}$ & $J=30 \mathrm{~Hz}$ & $J=19 \mathrm{~Hz}$ & $(11 \mathrm{H}, \mathrm{m})$ & & & & & & & & \\
\hline \multirow[t]{2}{*}{6} & - I & 1,595 & 680 & 531 & $3090-2852$ & - & 3.04 & 3.78 & 5.21 & $6.74-6.69$ & - & 6 & $4-1$ & 156.11 & 43.52 & 64.21 & $93.16-143.45$ & - \\
\hline & & & & & & & $J=24 \mathrm{~Hz}$ & $J=29 \mathrm{~Hz}$ & $J=20 \mathrm{~Hz}$ & $(11 \mathrm{H}, \mathrm{m})$ & & & & & & & & \\
\hline \multirow[t]{2}{*}{7} & $4-\mathrm{OCH}_{3}$ & 1,596 & 670 & 553 & $3095-2852$ & 1,249 & 3.07 & 3.77 & 5.24 & $6.75-7.28$ & 3.80 & 7 & $4-\mathrm{OCH}_{3}$ & 155.81 & 43.75 & 64.29 & $113.57-159.13$ & 55.28 \\
\hline & & & & & & & $J=25 \mathrm{~Hz}$ & $J=31 \mathrm{~Hz}$ & $J=18 \mathrm{~Hz}$ & $(11 \mathrm{H}, \mathrm{m})$ & & & & & & & & \\
\hline \multirow[t]{2}{*}{8} & $4-\mathrm{CH}_{3}$ & 1,594 & 680 & 546 & $3095-2854$ & - & 3.07 & 3.77 & 5.25 & $6.71-7.34$ & 2.31 & 8 & $4-\mathrm{CH}_{3}$ & 156.10 & 43.72 & 64.47 & $111.68-146.48$ & 21.13 \\
\hline & & & & & & & $J=24 \mathrm{~Hz}$ & $J=28 \mathrm{~Hz}$ & $J=19 \mathrm{~Hz}$ & $(11 \mathrm{H}, \mathrm{m})$ & & & & & & & & \\
\hline
\end{tabular}


Table 3 The HOMOCOSY and HSQC data $\delta$ (parts per million) of 1-phenyl-3(5-bromothiophen-2-yl)-5-(phenyl)-2pyrazoline (1)

\begin{tabular}{|c|c|c|c|c|c|c|c|c|c|c|}
\hline \multicolumn{6}{|c|}{ HOMOCOSY } & \multicolumn{5}{|c|}{ HSQC } \\
\hline Proton & $\begin{array}{l}\text { Carbon } \\
\text { (ppm) }\end{array}$ & $\begin{array}{l}\delta \mathrm{H}_{\mathrm{a}} \text { at } \\
\mathrm{C}_{4} 3.06\end{array}$ & $\begin{array}{l}\delta \mathrm{H}_{\mathrm{b}} \text { at } \\
\mathrm{C}_{4} 3.77\end{array}$ & $\begin{array}{l}\delta \mathrm{H}_{\mathrm{c}} \text { at } \\
\mathrm{C}_{5} 5.25\end{array}$ & $\begin{array}{l}\delta \mathrm{Ar}-\mathrm{H} \\
6.71-7.34\end{array}$ & Proton & $\begin{array}{l}\text { Carbon } \\
\text { (ppm) }\end{array}$ & $\delta C_{4} 43.66$ & $\begin{array}{l}\delta C_{5} \\
64.68\end{array}$ & $\begin{array}{l}\delta \mathrm{Ar}-\mathrm{H} \\
111.77-46.52\end{array}$ \\
\hline$\delta \mathrm{H}_{\mathrm{a}}$ at $\mathrm{C}_{4}$ & 3.06 & - & Bonded & Bonded & - & $\delta \mathrm{Ha}$ at $\mathrm{C} 4$ & 3.06 & Bonded & - & - \\
\hline$\delta \mathrm{H}_{\mathrm{b}}$ at $\mathrm{C}_{4}$ & 3.77 & Bonded & - & Bonded & - & $\delta \mathrm{Hb}$ at $\mathrm{C} 4$ & 3.77 & Bonded & - & - \\
\hline$\delta \mathrm{H}_{c}$ at $\mathrm{C}_{5}$ & 5.25 & Bonded & Bonded & - & - & $\delta \mathrm{Hc}$ at $\mathrm{C} 5$ & 5.25 & - & Bonded & - \\
\hline$\delta \mathrm{Ar}-\mathrm{H}$ & $6.71-7.34$ & - & - & - & Bonded & $\delta \mathrm{Ar}-\mathrm{H}$ & $6.71-7.34$ & - & - & Bonded \\
\hline
\end{tabular}

HOMOCOSY, homonuclear correlation spectroscopy; HSQC, heteronuclear single quantum correlation.

to $\mathrm{C}-\mathrm{H}$ stretching vibrations of the aliphatic and aromatic groups. These IR bands are supporting evidences for the formation of pyrazolines. The assigned spectral bands of pyrazolines are presented in Table 2.

\section{NMR spectral study}

\section{${ }^{1}$ H NMR spectra}

In ${ }^{1} \mathrm{H}$ NMR spectrum of pyrazolines, the doublet of doublet at $\delta 3.01$ to 3.10 with coupling constants $J_{1}=7.5 \mathrm{~Hz}$ and $J_{2}=17 \mathrm{~Hz}$ is assigned to $\mathrm{H}_{\mathrm{a}}$ proton of $\mathrm{C}_{4}$. The doublet of doublet at 3.76 to $3.93 \mathrm{ppm}$ with coupling constants $J_{1}=12.5 \mathrm{~Hz}$ and $J_{2}=17 \mathrm{~Hz}$ is assigned to $\mathrm{H}_{\mathrm{b}}$ proton of $\mathrm{C}_{4}$. Similarly, the doublet of doublet at 5.17 to $5.66 \mathrm{ppm}$ with coupling constants $J_{1}=7.5 \mathrm{~Hz}$ and $J_{2}=12.5 \mathrm{~Hz}$ is assigned to $\mathrm{H}_{\mathrm{c}}$ proton of $\mathrm{C}_{5}$. The aromatic protons appeared in the range of 6.71 to $7.34 \mathrm{ppm}$. These proton chemical shift (part per million) values were supported for formation of pyrazolines and are presented in Table 2 .

\section{${ }^{13}$ C NMR spectra}

In ${ }^{13} \mathrm{C}$ NMR spectrum of pyrazolines, the signals appear in the range 111.77 to $146.52 \mathrm{ppm}$ are due to the aromatic carbons. The signal at downfield region
$155.60 \mathrm{ppm}$ are assigned to $\mathrm{C}=\mathrm{N}$ carbon. Two signals that appeared in the lower frequency region at 43.66 and $64.68 \mathrm{ppm}$ are assigned to the methylene and methyn carbons at $\mathrm{C}_{4}$ and $\mathrm{C}_{5}$, respectively. The assigned ${ }^{13} \mathrm{C}$ chemical shift values of all pyrazolines are furnished in Table 2 .

\section{HOMOCOSY spectra}

In the homonuclear correlation spectroscopy (HOMOCOSY) spectrum of pyrazolines, the possible correlations are furnished in Table 3. The ${ }^{1} \mathrm{H}^{-}{ }^{1} \mathrm{H}$ COSY spectrum of parent compound (entry 1) is shown in Figure 1. Both $\mathrm{H}_{\mathrm{a}}$ (3.06 $\mathrm{ppm}$ ) and $\mathrm{H}_{\mathrm{b}}(3.77 \mathrm{ppm})$ protons at $\mathrm{C}_{4}$ show a strong cross peak with the signal at $5.25 \mathrm{ppm}$. This suggests that the doublet of doublet at $5.25 \mathrm{ppm}$ is due to the $\mathrm{H}_{\mathrm{c}}$ proton of $\mathrm{C}_{4}$. Based on this analysis, the proton chemical shifts (parts per million) of other pyrazolines were assigned and confirmed.

\section{HETCOSY spectra}

The HSQC (heteronuclear single quantum correlation) spectrum of synthesized pyrazoline (entry 1) is shown in Figure 2, and their correlations are listed in Table 3. The $\mathrm{H}_{\mathrm{a}}$ and $\mathrm{H}_{\mathrm{b}}$ protons at $\mathrm{C}_{4}$ show a cross peak with

Table 4 The antibacterial and antifungal activities of 1-phenyl-3(5-bromothiophen-2-yl)-5-(substitutedphenyl)-2pyrazolines by disc diffusion method

\begin{tabular}{|c|c|c|c|c|c|c|c|c|c|c|c|}
\hline \multicolumn{7}{|c|}{ Antibacterial activities } & \multicolumn{5}{|c|}{ Antifungal activities } \\
\hline \multicolumn{2}{|c|}{ Entry $\mathrm{X}$} & \multicolumn{5}{|c|}{ Zone of inhibition $(\mathrm{mm})$} & \multirow[t]{2}{*}{ Entry $\mathrm{X}$} & \multicolumn{4}{|c|}{ Zone of inhibition (mm) } \\
\hline & & S. aureus & E. coli & K. pneumoniae & S. typhi & Pseudomonas spp. & & C. albicans & Mucor spp. & Rhizopus spp. & A. niger \\
\hline 1 & $\mathrm{H}$ & 10 & 15 & 20 & 15 & 15 & 1 & 15 & 15 & 15 & 15 \\
\hline 2 & $4-\mathrm{Br}$ & 10 & 15 & 20 & 20 & 17 & 2 & 20 & 20 & 20 & 20 \\
\hline 3 & $2-\mathrm{Cl}$ & 15 & 15 & 15 & 5 & 5 & 3 & 15 & 15 & 15 & 15 \\
\hline 4 & $4-\mathrm{Cl}$ & 3 & 10 & 15 & 15 & 15 & 4 & 15 & 15 & 15 & 15 \\
\hline 5 & $3,4-\left(\mathrm{OCH}_{3}\right)_{2}$ & 17 & 17 & 15 & 17 & 20 & 5 & 17 & 17 & 17 & 17 \\
\hline 6 & $4-1$ & 15 & 17 & 20 & 17 & 10 & 6 & 17 & 17 & 17 & 17 \\
\hline 7 & $4-\mathrm{OCH}_{3}$ & 15 & 17 & 20 & 17 & 22 & 7 & 20 & 20 & 20 & 20 \\
\hline 8 & $4-\mathrm{CH}_{3}$ & 15 & 10 & 15 & 5 & 5 & 8 & 20 & 15 & 15 & 20 \\
\hline Cip & - & 17 & 17 & 20 & 22 & 15 & Ket & 15 & 15 & 15 & 15 \\
\hline
\end{tabular}

Cip, ciprofloxacin; Ket, ketoconazole. 


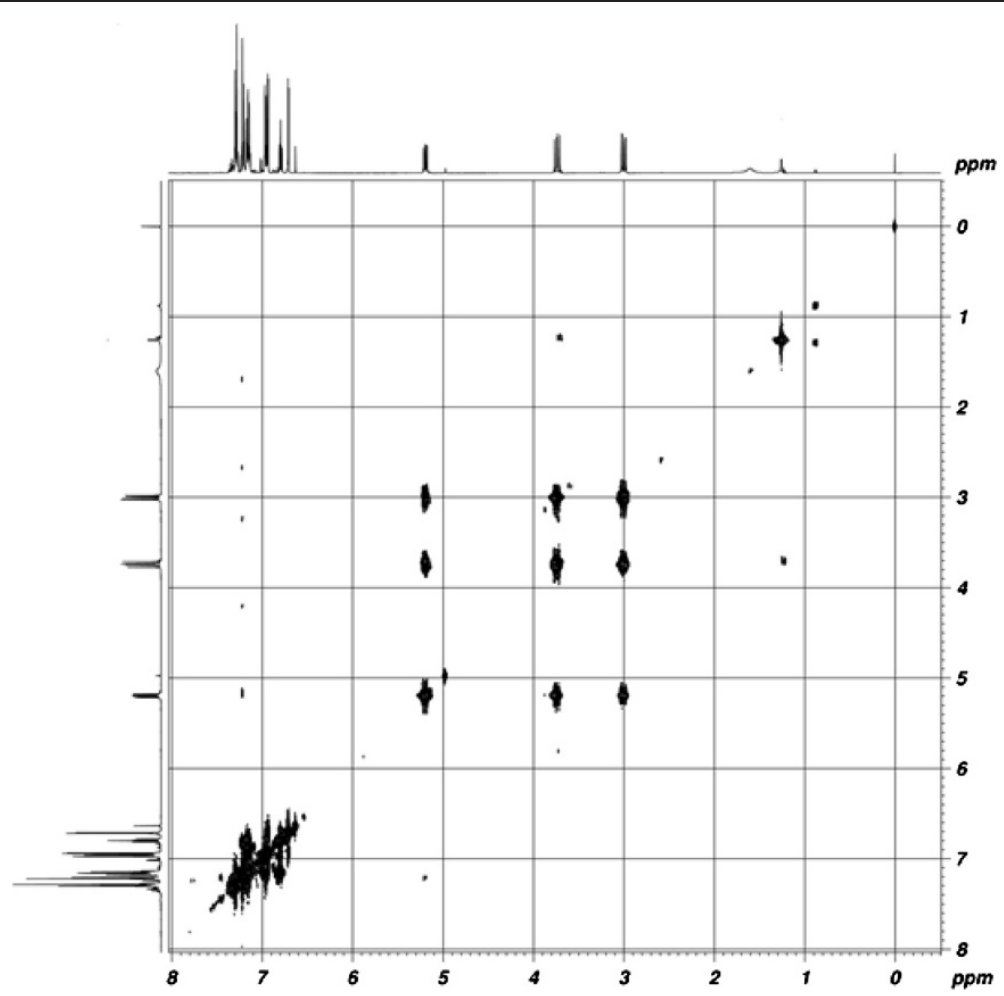

Figure 1 HOMOCOSY spectrum of 1-phenyl-3(5-bromothiophen-2-yl)-5-(phenyl)-2-pyrazoline (1).

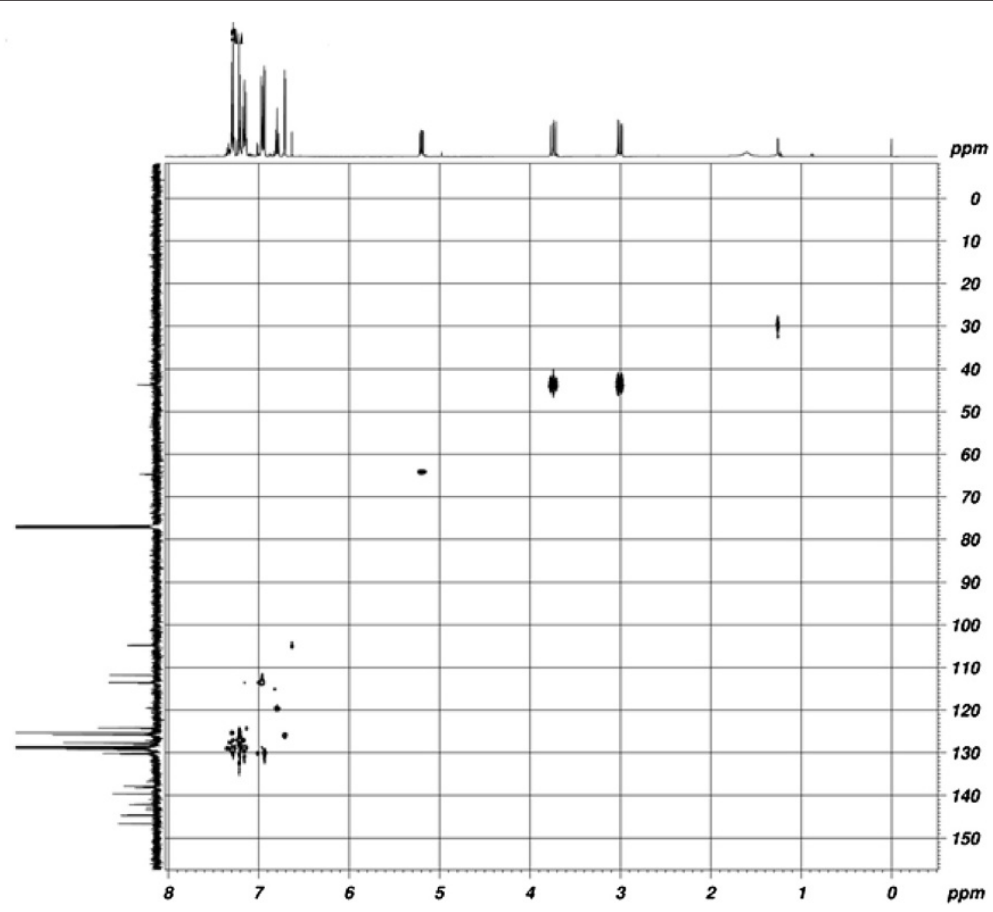

Figure 2 HSQC spectrum of 1-phenyl-3(5-bromothiophen-2-yl)-5-(phenyl)-2-pyrazoline (1). 


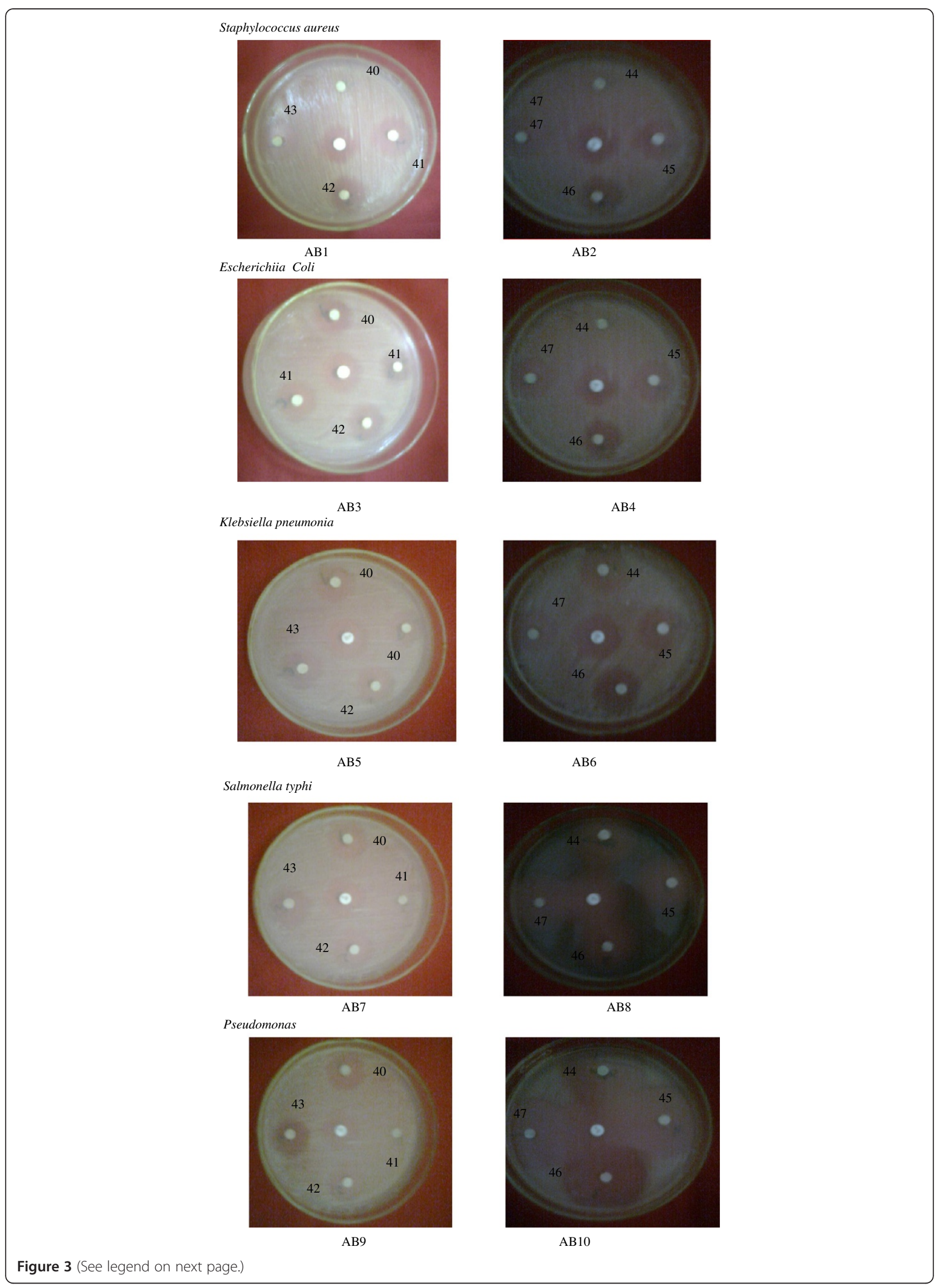


the carbon signal at $43.66 \mathrm{ppm}$, which confirms that this carbon signal is due to $\mathrm{C}_{4}$ carbon. Similarly, a doublet of doublet at $5.25 \mathrm{ppm}$ is having a strong correlation with the carbon resonance at $64.68 \mathrm{ppm}$. From this, it is inferred that the carbon signal is due to $C_{5}$ carbon. Based on this analysis, the carbon chemical shifts (parts per million) of other pyrazolines were assigned and confirmed.

\section{Antimicrobial activities}

\section{Antibacterial activity}

Staphylococcus aureus was taken as gram positive strain, and Escherichia coli, Klebsiella pneumoniae, Salmonella typhi, and Pseudomonas species were taken as gram negative strains; they have been used for the present study.

\section{Determination of antibacterial activity by disc-diffusion method}

Nutrient agar plates were prepared under sterilized conditions and incubated overnight to detect contamination. About $0.2 \mathrm{~mL}$ of working stock culture was transferred into separate nutrient broth and spread thoroughly using a glass spreader. Whatman number 1 discs $(6 \mathrm{~mm}$ in diameter) were impregnated with the test compounds dissolved in DMSO $(200 \mu \mathrm{g} / \mathrm{mL})$ for about half an hour. Commercially available drug disc (ciprofloxacin $10 \mathrm{mg} / \mathrm{disc}$ ) was used as positive reference standard. Negative control was also prepared by impregnating the disc of same size in dimethyl sulfoxide (DMSO) solvent. The plates were then incubated overnight for 18 to $24 \mathrm{~h}$. Antibacterial activity was evaluated by measuring the zone of inhibition against the test organism.

\section{Determination of minimum inhibitory concentration of test compounds using twofold serial dilution method}

Testing was done in the seeded broth $\left(10^{-6}\right.$ to $10^{-7} \mathrm{cfu} /$ $\mathrm{mL})$. The test compounds were taken at different concentrations ranging from 200, 100, 50, 25, 12.5, 6.25, $3.13,1.56,0.78$, and to $0.39 \mu \mathrm{g} / \mathrm{mL}$ for finding the minimum inhibitory concentration (MIC) by using seeded broth as diluent. Similarly, the standard solution of ciprofloxacin drug prepared at the concentrations of $200,100,50,25.5,6.25,3.13,1.56,0.78$, and $0.39 \mu \mathrm{g} / \mathrm{mL}$ of sterile distilled water and DMSO were maintained throughout the experiment simultaneously as control.

The study involves a series of 10 assay tubes for the test compounds against each strain. In the first assay tube, $1.6 \mathrm{~mL}$ of seeded broth was transferred, and $0.4 \mathrm{~mL}$ of the test solution was added, followed by mixing it thoroughly to obtain a concentration of $200 \mu \mathrm{g} / \mathrm{mL}$. To the remaining nine assay tubes, $1 \mathrm{~mL}$ of seeded broth was transferred, and then, from the first assay tube, per milliliter of the content was pipetted out and added into the second assay tube, followed by mixing thoroughly. This type of dilution was repeated up to the 10th assay tube serially. The same procedure was followed for standard drugs. Duplicates were also maintained; these were done under aseptic conditions.

The racks of assay tubes were placed inside the incubator at $37 \pm 1^{\circ} \mathrm{C}$ for $24 \mathrm{~h}$. After the incubation period, the assay tube concentrations were again streaked into the nutrient agar plate due to turbidity of the drug microorganism mixture. The lowest concentration of the test compounds, which caused apparently a complete inhibition of growth of organisms, was taken as the MIC. The solvent control tube was also observed to find whether there was any inhibitory action. The sterile distilled water and DMSO did not show any inhibition.

The antimicrobial activity of all the synthesized pyrazolines (entries 1 to 8 ) were examined by disc diffusion and two fold serial dilution methods. Bacterial strains, viz. S. aureus, E. coli, K. pneumonia, S. typhi, and Pseudomonas species, and fungal strains, viz. Candida albicans, Mucor species, Rhizopus species, Aspergillus niger. In the present study, DMSO is used as control, while ciprofloxacin and ketoconazole are used as standards for bacterial and fungal strains, respectively. The zone of inhibition and MIC values of compounds (entries 1 to 8 ) against both the tested bacterial strains are given in Table 4. The representative photographs of disc diffusion and serial dilution methods are depicted in Figure 3.

The antibacterial activity of all pyrazolines produced a maximum zone of inhibition against all the bacterial strains except compounds 3 and 4 against S. typhi and Pseudomonas spp., compounds 4 against $S$. aureus, and compounds 7 and 8 against Pseudomonas spp. which showed maximum zone of inhibition than the standard (ciprofloxacin).

Antibacterial activity of all synthesized pyrazolines was measured by serial dilution method, and the MICs are presented in Table 5. From Table 5, compounds 1 to 8 showed the growth inhibitory concentration against the tested organism fall in the range of 1.5 to $200 \mu \mathrm{g} / \mathrm{mL}$. However, compounds 1 to 4 showed the inhibition against all bacterial strains in the range from 25 to $100 \mu \mathrm{g} / \mathrm{mL}$. The rest of the compounds are more effective against all bacterial strain MICs at 1.5 to $25 \mu \mathrm{g} / \mathrm{mL}$. 
Table 5 The antibacterial and antifungal activities of 1-phenyl-3(5-bromothiophen-2-yl)-5-(substituted phenyl)-2pyrazolines by serial dilution method

\begin{tabular}{|c|c|c|c|c|c|c|c|c|c|c|c|}
\hline \multicolumn{7}{|c|}{ Antibacterial activities } & \multicolumn{5}{|c|}{ Antifungal activities } \\
\hline \multicolumn{2}{|c|}{ Entry $\mathrm{X}$} & \multicolumn{5}{|c|}{ MIC $(\mu \mathrm{g} / \mathrm{mL})$} & \multirow[t]{2}{*}{ Entry $\mathrm{X}$} & \multicolumn{4}{|c|}{ MIC $(\mu \mathrm{g} / \mathrm{mL})$} \\
\hline & & S. aureus & E. coli & K. pneumoniae & S. typhi & Pseudomonas spp. & & C. albicans & Mucor spp. & Rhizopus spp. & A. niger \\
\hline 1 & $\mathrm{H}$ & 25 & 50 & 12.5 & 50 & 50 & 1 & 50 & 50 & 50 & 50 \\
\hline 2 & $4-B r$ & 50 & 25 & 3.13 & 3.13 & 6.25 & 2 & 3.13 & 3.13 & 3.13 & 3.13 \\
\hline 3 & $2-\mathrm{Cl}$ & 25 & 25 & 25 & 100 & 100 & 3 & 25 & 25 & 25 & 25 \\
\hline 4 & $4-\mathrm{Cl}$ & 200 & 50 & 25 & 25 & 25 & 4 & 25 & 25 & 25 & 3.13 \\
\hline 5 & $3,4-\left(\mathrm{OCH}_{3}\right)_{2}$ & 6.25 & 6.25 & 12.5 & 6.25 & 3.13 & 5 & 6.25 & 6.25 & 6.25 & 6.25 \\
\hline 6 & $4-1$ & 25 & 6.25 & 3.13 & 6.25 & 50 & 6 & 6.25 & 6.25 & 6.25 & 6.25 \\
\hline 7 & $4-\mathrm{OCH}_{3}$ & 12.5 & 6.25 & 3.13 & 6.25 & 1.5 & 7 & 3.13 & 3.13 & 3.13 & 3.13 \\
\hline 8 & $4-\mathrm{CH}_{3}$ & 50 & 100 & 50 & 200 & 200 & 8 & 50 & 50 & 50 & 50 \\
\hline Cip & - & 6.25 & 6.25 & 3.13 & 1.5 & 12.5 & Ket & 12.5 & 12.5 & 12.5 & 12.5 \\
\hline
\end{tabular}

Cip, ciprofloxacin; Ket, ketoconazole.

\section{Antifungal activity}

The following fungal strains C. albicans, Mucor spp, Rhizopus spp, and A. niger were used for the present study. Sabouraud dextrose agar (SDA) medium was used for the growth of fungi, and testing was done in Sabouraud dextrose broth (SDB) medium.

The subculture and the viable count were carried out by the same procedure as done in antibacterial studies except for the temperature which should be maintained at $28 \pm 1^{\circ} \mathrm{C}$ for about $72 \mathrm{~h}$. Similarly, for the disc diffusion method, the petri dishes were incubated at $28 \pm 1^{\circ} \mathrm{C}$ for about $72 \mathrm{~h}$. The same concentration of the test compound, solvent (DMSO), and ketoconazole (standard) prepared previously were used for the antifungal studies.

The antifungal activities of synthesized pyrazolines 1 to 4 exhibited a similar inhibition activity as that of the standard $(15 \mathrm{~mm})$ against all fungal strains, whereas pyrazoline 2 exhibited against $C$. albicans and A. niger $(20 \mathrm{~mm})$, and pyrazoline 5 to 8 against all the fungal strains showed maximum zone of inhibition (17 to $20 \mathrm{~mm}$ ) than the standards (15 $\mathrm{mm}$, ketoconazole). The measured antifungal activities of pyrazolines are presented in Table 4. The representative photographs of disc diffusion methods are depicted in Figure 4.

The antifungal activities of all synthesized pyrazolines were measured by serial dilution method. Among the compounds under study, compounds 1 to 8 were found to be effective against all the fungal strain MICs at 3.13 to $6.25 \mu \mathrm{g} / \mathrm{mL}$. MIC values of compounds 1 to 4 against all the tested fungal strains are in the range of 25 to $50 \mu \mathrm{g} / \mathrm{mL}$ except for compound 2 against $C$. albicans $(12.5 \mu \mathrm{g} / \mathrm{mL})$ and compound 4 against $A$. niger $(3.13 \mu \mathrm{g} /$ $\mathrm{mL})$. The measured antifungal activities of all compounds are presented in Table 5 .
Comparison of potency of compounds 1 to 8 with standard drugs against bacterial and fungal strains from serial dilution method

In order to understand the results of serial dilution method, the potency of synthesized compounds 1 to 8 against tested bacterial and fungal strains are calculated with respect to the reference (standards) using Equation 1:

$$
\text { Potency } \begin{aligned}
(\%)= & \frac{\text { M IC }(\mathrm{mg} / \mathrm{mL}) \text { of reference compound }}{\text { M IC }(\mathrm{mg} / \mathrm{mL}) \text { of tested compound }} \\
& \times 100
\end{aligned}
$$

To comprehend it well, the results obtained from the above equation are presented as bar graphs and are shown in Figures 5 and 6.

On comparison with ciprofloxacin compounds 1-4 showed the potency against all the bacterial strains in the range of $25-100 \%$. But, the remaining compounds exhibited lesser potency in the range of $1.5-50 \%$.

With reference to ketoconazole, an equal potency is noted for compounds 1 (50\%), 3(25\%), 5 and 7 (3.13\%), 6 and 8 (6.25\%) against all the fungal strains. But 12.5\% potency is noted for compound 2 against C.albicans and $3.13 \%$ is noted for compound 4 against A. niger.

\section{Experimental}

\section{Preparation and characterization of catalyst}

In a 50-mL Borosil beaker (Borosil Glass Works Limited, Mumbai, India), $1 \mathrm{~g}$ of fly ash and $0.8 \mathrm{~mL}(0.5 \mathrm{~mol})$ of sulphuric acid were taken and mixed thoroughly with glass rod. This mixture was heated on a hot air oven at $85^{\circ} \mathrm{C}$ for $1 \mathrm{~h}$, cooled to room temperature, stored in a Borosil bottle, and tightly capped [42]. This was 


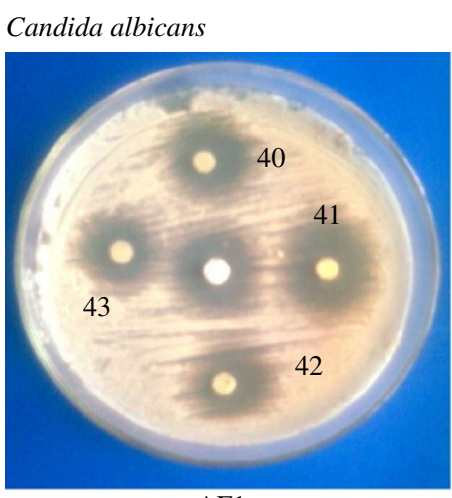

AF1

Mucor.sp

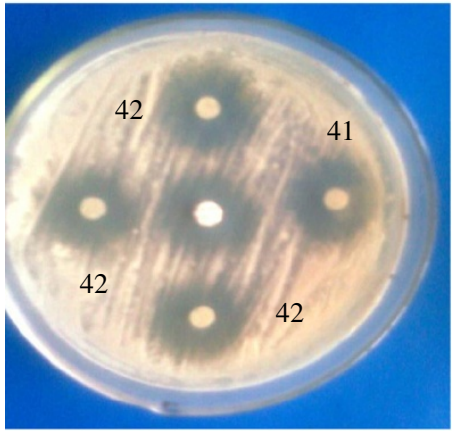

AF3

Rhizopus sp

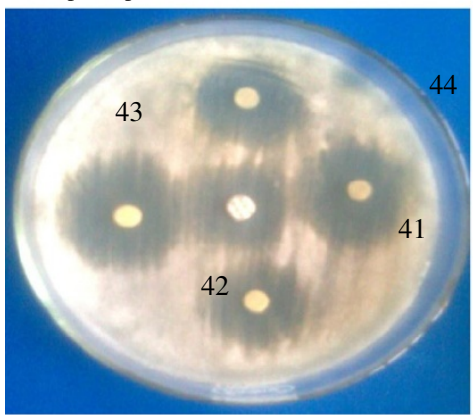

AF5

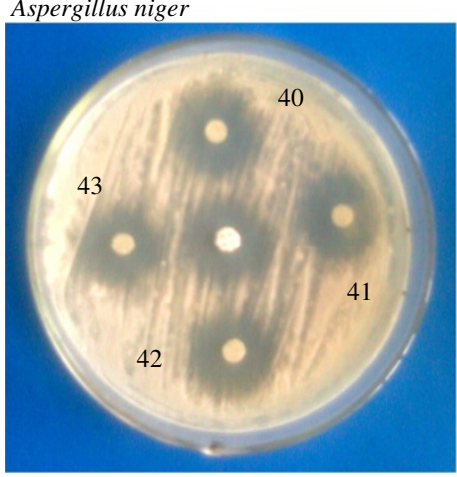

AF7

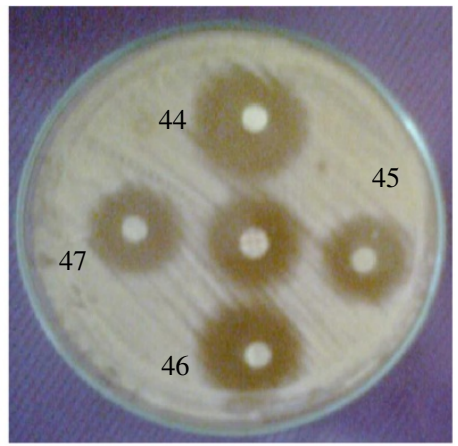

AF2

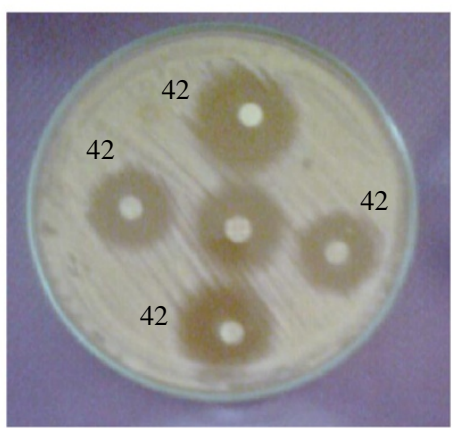

AF4

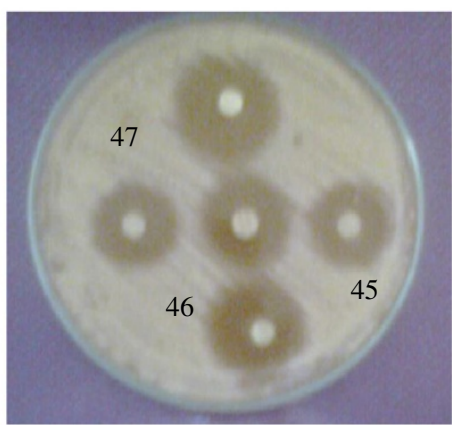

AF6

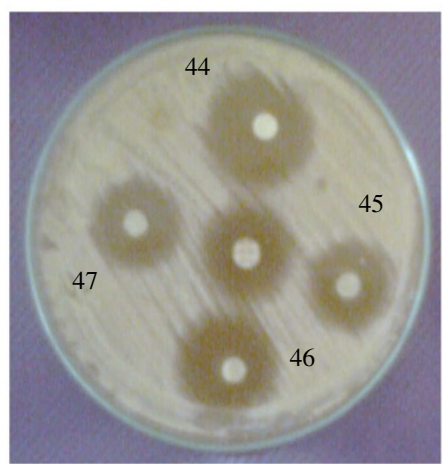

AF8

Figure 4 Antifungal activities of spectrum of 1-phenyl-3(5-bromothiophen-2-yl)-5-(substituted phenyl)-2-pyrazoline pretri dishes (AF1 to AF8). 


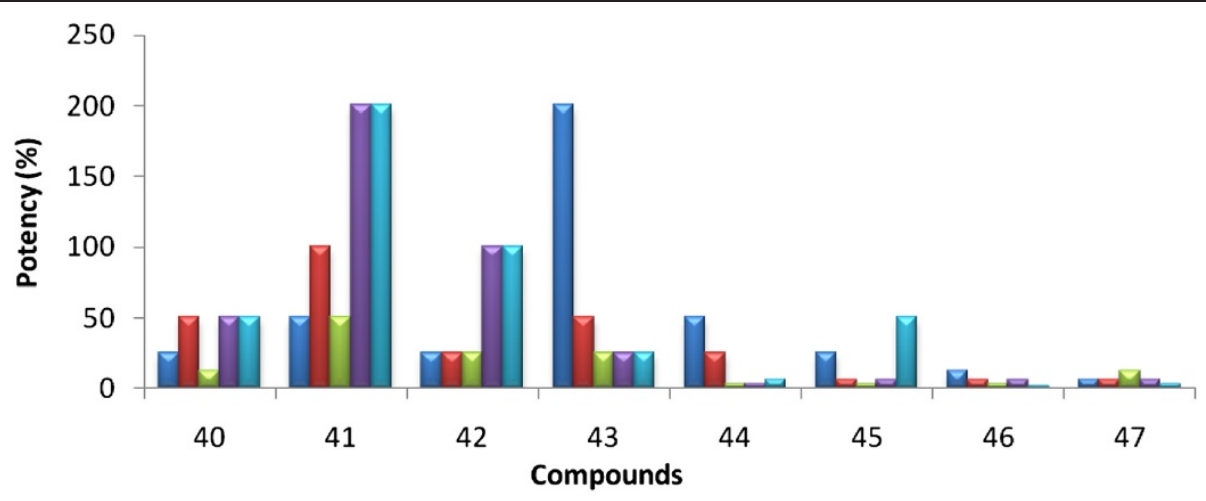

S.aureas $\square$ E.coli $\square$ K.pneumoniae $\square$ S.typhi $\square$ Pseudomonas

Figure 5 Comparison of potency of pyrazolines with ciprofloxacin (standard) against bacterial strains from serial dilution method.

characterized by infrared spectra and scanning electron microscopy (SEM) analysis.

Infrared spectral data of fly ash: $\mathrm{H}_{2} \mathrm{SO}_{4}$ is $v$ (per centimeter) with values $3,456(\mathrm{OH}) ; 3,010(\mathrm{C}-\mathrm{H}) ; 1,495,1,390$ (C-S); 1,336, 1,154( $\mathrm{S}=\mathrm{O})$ and op modes $1,136,1,090$, $976,890,850,820,667,658,620,580,498$, and 425.

The SEM images of pure fly ash and fly ash: $\mathrm{H}_{2} \mathrm{SO}_{4}$ at two different magnifications are shown in Figure 7 . Figure 1a,b depicted that there is more crystallinity found in pure fly ash. The spherical-shaped particles are clearly seen at both magnifications in Figure 7a,b. Figure 7a reveals the globular structure of pure fly ash (round-shaped particle). This is also seen in Figure 7c,d that some of the particles are slightly corroded by $\mathrm{H}_{2} \mathrm{SO}_{4}$ (indicated by arrow mark), and this may be due to dissolution of fly ash by $\mathrm{H}_{2} \mathrm{SO}_{4}$. This will further be confirmed by Figure $7 \mathrm{~d}$, the well-shaped particles of pure fly ash. Figure $7 \mathrm{~b}$ is aggregated to Figure $7 \mathrm{~d}$ due to the presence of $\mathrm{H}_{2} \mathrm{SO}_{4}$.

Synthesis of substituted 5-bromo-2-thienyl chalcones All substituted styryl 5-bromo-2-thienyl ketones were synthesized using the literature procedure [43].
Synthesis of 1-phenyl-3(5-bromothiophen-2-yl)-5(substituted phenyl)-2-pyrazolines

An appropriate equi-molar quantity of 5-bromo-2-thienyl chalcones, phenylhydrazine hydrochloride $(0.2 \mathrm{mmol})$, and $0.5 \mathrm{~g}$ of fly ash: $\mathrm{H}_{2} \mathrm{SO}_{4}$ was subjected to microwave irradiation for 5 to $6 \mathrm{~min}$ in a microwave oven (Scheme 1) (LG Grill, Intellowave, Microwave Oven, LG Electronics, Seoul, South Korea; 160 to $800 \mathrm{~W}$ ) and then cooled to room temperature. The organic layer was separated with dichloromethane, and the solid product was obtained on evaporation. On recrystallization with benzene-hexane mixture, it gave glittering pale yellow solid. The insoluble catalyst was recycled by washing the solid reagent that remained on the filter by ethyl acetate $(8 \mathrm{~mL})$, followed by drying in an oven at $100^{\circ} \mathrm{C}$ for $1 \mathrm{~h}$, and it was made reusable for further reactions. The analytical and mass spectral data are given in Table 1. Infrared and NMR spectral data of pyrazolines are presented in Table 2. The individual proton and carbon signals were unambiguously assigned by HOMOCOSY and HETCOSY spectral analysis. The ${ }^{1} \mathrm{H}_{-}{ }^{1} \mathrm{H}$ COSY and ${ }^{1} \mathrm{H}_{-}{ }^{13} \mathrm{C}$ COSY spectral data are presented in Table 3.

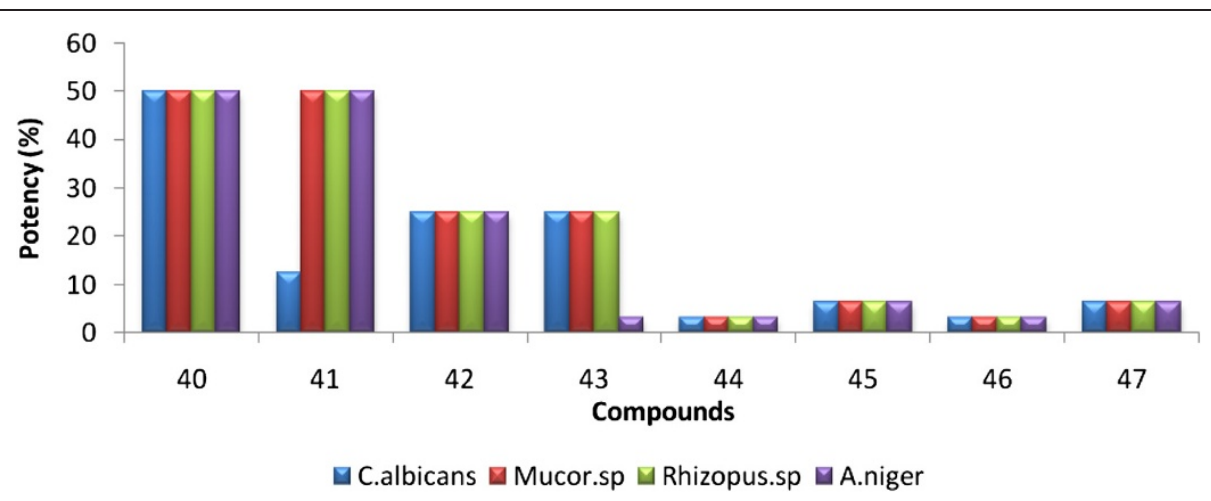

Figure 6 Comparison of potency of pyrazolines with ciprofloxacin (standard) against fungal strains from serial dilution method. 

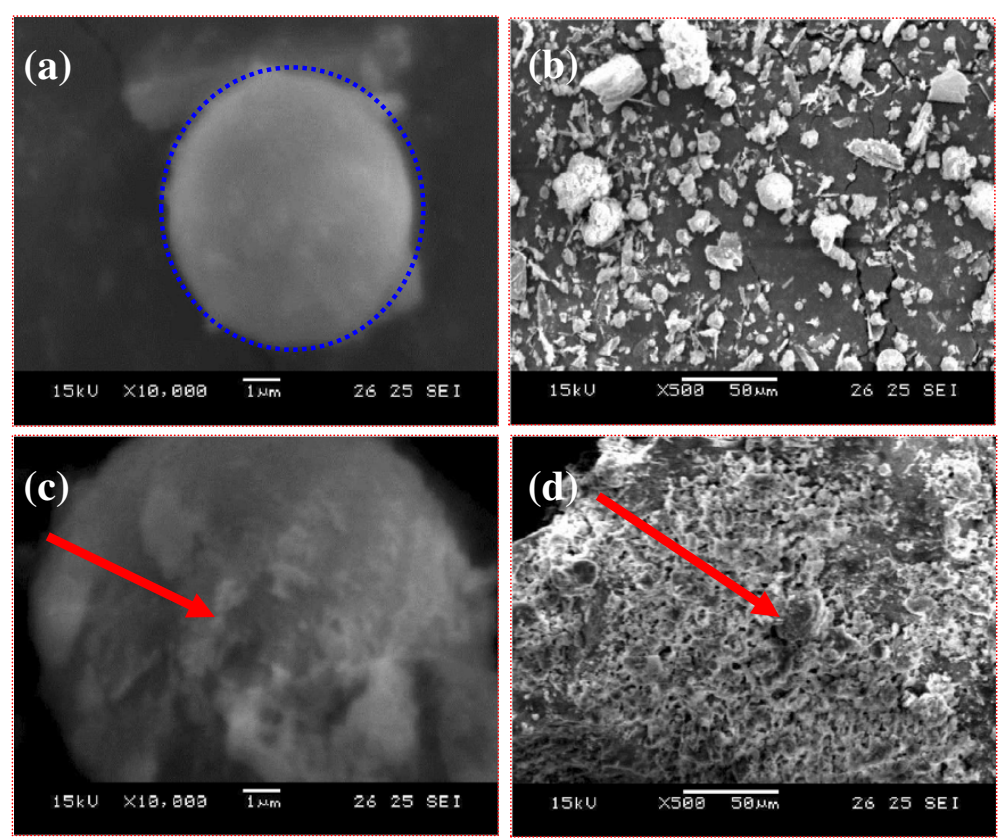

Figure 7 SEM images of pure fly ash and fly ash:H2SO4. (a) Pure fly ash $(1 \mu \mathrm{m}),(\mathbf{b})$ pure fly ash $(50 \mu \mathrm{m})$, (c) fly ash: $\mathrm{H}_{2} \mathrm{SO}_{4}(1 \mu \mathrm{m})(\mathrm{red}$ bold arrow, corroded), and (d) fly ash: $\mathrm{H}_{2} \mathrm{SO}_{4}(50 \mu \mathrm{m})$ (red bold arrow, corroded).

\section{Antibacterial activities}

\section{Preparation of test inoculum subculture (preparation of seeded broth)}

The strains of S. aureus, E. coli, K. pneumoniae, Pseudomonas species, and S. typhi were inoculated in conical flasks containing $100 \mathrm{~mL}$ of sterile nutrient broth. These conical flasks were incubated at $37 \pm 1^{\circ} \mathrm{C}$ for $24 \mathrm{~h}$. This was referred to as the seeded broth.

\section{Standardization of seeded broth (viable count) dilutions}

One $\mathrm{mL}$ of 24-h seeded broth of each strain was diluted with $99 \mathrm{~mL}$ of sterile normal saline containing $0.05 \%$ Tween 80 (drops of Tween 80 in 1,000 mL normal saline). From that, $1 \mathrm{~mL}$ is further diluted to $10 \mathrm{~mL}$ sterile normal saline. This was continued to $10^{-2}, 10^{-3}, 10^{-4}, 10^{-5}$, until $10^{-10}$ dilution of seeded broth was obtained.

\section{Incubation of nutrient agar petri dishes}

The dilutions were studied by inoculating $0.2 \mathrm{~mL}$ of each dilution onto the solidified nutrient agar medium by spread plate method, after incubation at $37 \pm 1^{\circ} \mathrm{C}$ for $24 \mathrm{~h}$. The numbers of well-formed colonies on the plates were counted. The seeded broth was then suitably diluted to have been $10^{5}$ to $10^{7}$ microorganisms per milliliter or colony-forming per milliliter. This was designated as the working stock and used for the antibacterial studies.

\section{Preparation of solution of test compounds}

The solution of test compounds were prepared by dissolving the same in DMSO in a specific growth bottle and stored in a refrigerator. The solution was removed from the refrigerator $1 \mathrm{~h}$ prior to its use and allowed to

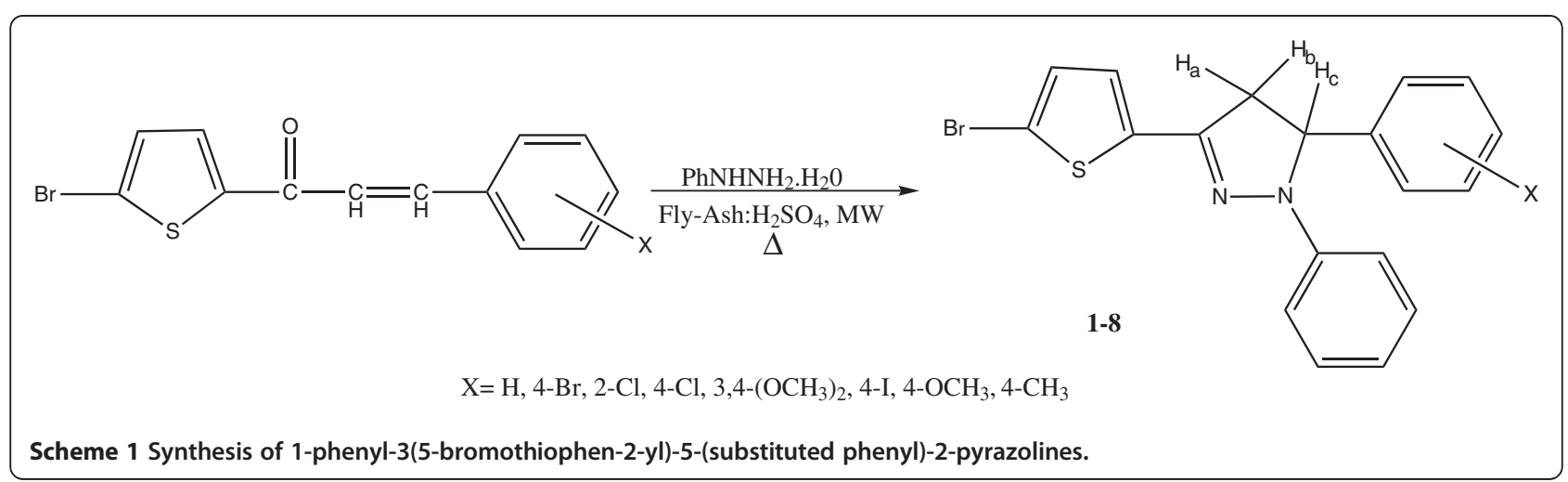


warm up to room temperature. The test compounds were prepared at a concentration of $200 \mu \mathrm{g} / \mathrm{mL}$. Similarly, the standard drug solution of ciprofloxacin and ketoconazole were used respectively at a concentration of $200 \mu \mathrm{g} / \mathrm{mL}$ for finding the MIC.

\section{Preparation of culture media}

The media used for the growth of bacteria were nutrient agar medium and nutrient broth medium. The media were sterilized by autoclaving at a pressure of $15 \mathrm{lbs}$ at $121^{\circ} \mathrm{C}$ for $20 \mathrm{~min}$.

Nutrient agar medium The nutrient agar medium was prepared by dissolving $28 \mathrm{~g}$ of nutrient agar (Hi-media, Mumbai, India) in $1,000 \mathrm{~mL}$ of distilled water. The following formula was followed for the preparation of nutrient agar medium: peptone, $1 \%$; $\mathrm{NaCl}, 0.5 \%$; beef extract, $1 \%$; agar, $2 \%$, and $\mathrm{pH}, 7.4 \pm 0.2$.

Nutrient broth medium The nutrient broth medium was prepared by dissolving $13 \mathrm{~g}$ of nutrient broth (Himedia, Mumbai) in $1000 \mathrm{~mL}$ of distilled water. The following formula was followed for preparation of nutrient broth medium: peptone $1 \% ; \mathrm{NaCl}, 0.5 \%$; beef extract, $1 \%$; agar, $1 \%$; $\mathrm{pH}, 7.4 \pm 0.2$.

\section{Antifungal activity Preparation of culture media SDA medium}

The following formula was followed for the preparation of SDA medium: dextrose, $40 \mathrm{~g}$; peptone, $10 \mathrm{~g}$; agar, $15 \mathrm{~g}$; distilled water, $1,000 \mathrm{~mL}$, and $\mathrm{pH}, 5.4$.

\section{SDB broth}

The following formula was followed for the preparation of SDB broth: dextrose, 40 g; peptone, $10 \mathrm{~g}$; agar, $15 \mathrm{~g}$; distilled water, $1,000 \mathrm{~mL}$; and $\mathrm{pH}, 5.4$.

\section{Conclusions}

We have developed an efficient catalytic method for synthesis of 1-phenyl-3(5-bromothiophen-2-yl)-5-(substituted phenyl)-2-pyrazolines by cyclization of substituted styryl 5-bromo-2-thienyl ketones and phenyl hydrazine hydrochloride using a solvent-free environmentally greener catalyst fly ash: $\mathrm{H}_{2} \mathrm{SO}_{4}$ under microwave irradiation. This reaction protocol offers a simple, economical, environment friendly, non-hazardous, and easier work-up procedure and good yields. All synthesized pyrazoline derivatives showed moderate antimicrobial activities against the strains used.

\section{Competing interests}

The authors declare that they have no competing interests.

\section{Acknowledgments}

The authors thank RSIC, IIT, Chennai-600 036 for recording the NMR spectra of all pyrazolines.

Received: 17 October 2011 Accepted: 24 April 2012

Published: 11 June 2012

\section{References}

1. Das BC, Bhowmilk D, Chiranjib B, Mariappan G (2010) Synthesis and biological evaluation of some pyrazoline derivatives. J Pharm Res 3(6):1345-1348

2. Gupta R, Gupta N, Jain A (2010) Improved synthesis of chalcones and pyrazolines under ultrasonic irradiation. Indian J Chem 49B(3):351-355

3. Solankee A, Lad S, Solankee S, Patel G (2009) Chalcones, pyrazolines and aminopyrimidines as antibacterial agents. Indian J Chem 48B(10):1442-1446

4. Revanasiddappa BC, Nagendr Rao R, Subramaniyam EVS, Satyanarayana D (2010) Synthesis and biological evaluation of some novel 1,3,5-trisubstituted pyrazolines. E-J Chem 7(1):295-298

5. Voskiene A, Mickevicius V, Mikulskiene G (2007) Synthesis and characterization of products condensation 4-carboxy-1-(4styrylcarbonylphenyl)-2-pyrrolidines with hydrazines. ARKIVOC XV:303-314

6. Kataade S, Phalgune U, Biswas S, Wakharkar R, Deshpande N (2008) Microwave studies on synthesis of biologically active chalcones derivatives Indian J Chem 47B(6):927-931

7. Al-Issa SA, Andis NAL (2005) Solvent free synthesis of chalcones and $\mathrm{N}$-phenyl-2-pyrazolines under microwave irradiation. J Saudi Chem Soc 9(3):687-692

8. Levai A, Jeko J (2007) Synthesis of carboxylic acid derivatives of 2-pyrazolines. ARKIVOC I:134-145

9. Powers DG, Casebier DS, Fokas D, Ryan WR, Troth JR, Coffen DL (1998) Automated parallel synthesis of chalcones based screening libraries. Tetrahedron 54(16):4085-4096

10. Kidwar K, Kukreja S, Thakur $\mathrm{R}$ (2006) $\mathrm{K}_{2} \mathrm{CO}_{3}$-Mediated regioselective synthesis of isoxazoles and pyrazolines. Lett Org Chem 3(2):135-139

11. Katritzky AR, Wang M, Zhang S, Voronkov MV, Steel PJ (2001) Regioselective synthesis of polysubstituted pyrazoles and isoxazoles. J Org Chem 66(20):6787-6791

12. Kuz'menok NM, Koval'chuk TK, Zvonok AM (2005) Synthesis of 5-hydroxyand 5-amino-1-tosyl-5- phenyl-3-(2-arylvinyl)-4,5-dihydropyrazoles. Syn Lett 3:485-486

13. Li CJ (2008) Organic reactions in aqueous media with a focus on C-C bond formations: a decade update. Chem Rev 105(3):3095-3165

14. Li JT, Zhang XH, Lin ZP (2007) An improved synthesis of 1,3,5-triaryl-2pyrazolines in acetic acid aqueous solution under ultrasound irradiation. Beli J Org Chem. doi:10.1186/1860-5397-3-13

15. Sahu SK, Banerjee M, Samantray A, Behera C, Azam MA (2008) Synthesis, analgesic, anti-inflammatory and antimicrobial activities of some novel pyrazoline derivatives. Trop J Pharm Res 7(2):961-968

16. Karabasanagouda T, Adhikari AV, Girisha M (2009) Synthesis of some new pyrazolines and isoxazoles carrying 4-methylthiophenyl moiety as potential analgesic and anti-inflammatory agents. Indian J Chem 48B(3):430-437

17. Barsoum FF, Hosni HM, Girgis AS (2006) Novel bis(1-acyl-2-pyrazolines) of potential anti-inflammatory and molluscicidal properties. Bioorg Med Chem 14(11):3929-3937

18. Kumar B, Pathak V, Rani S, Kant R, Tewari IC (2009) Synthesis and antimicrobacterial activity of some bromo-benzothiazolo pyrazolines. Int J Microbiol Res 1(2):20-22

19. Chawla R, Sahoo U, Arora A, Sharma PC, Radhakrishnan V (2010) Microwave assisted synthesis of some novel 1-pyrazoline derivatives as possible antimicrobial agents. Acta Polo Pharm-Drug Res 67(1):55-61

20. Mbarki S, Dguigui K, Hallaoui ME (2011) Construction of 3D-QSAR models to predict antiamoebic activities of pyrazoline and dioxazoles derivatives. J Mater Environ Sci 2(1):61-70

21. Rao NS, Kumar R, Srivastava YK (2009) Microwave induced synthesis and antimicrobial activities of some n1-morpholono ethanoyl-3,5-diaryl-2pyrazoline derivatives. Rasayan J Chem 2(3):716-719

22. Rahman MA, Siddiqui AA (2010) Pyrazoline derivatives: a worthy insight into the recent advances and potential pharmacological activities. Int J Pharm Sci Drug Res 2(3):165-175

23. Kasabe AJ, Kasabe PJ (2010) Synthesis, antitubercular and analgesic activity evaluation of new 3-pyrazoline derivatives. Int J Pharmacy Pharm Sci 2(2):132-135 
24. Sridevi C, Balaji K, Naidu A, Kavimani S, Venkappayya D, Suthakaran R, Parimala S (2009) Synthesis of some phenylpyrazolo benzothiazolo quinoxaline derivatives. Int J Pharm Tech Res 1(3):816-821

25. Levai A, Jeko J (2009) Synthesis of 5-aryl-1-carboxyphenyl-3-(3-coumarinyl)2-pyrazolines. ARKIVOC VI:63-70

26. Palaska E, Aytemir M, Uzbay IT, Erol D (2001) Synthesis and antidepressant activities of some 3,5-diphenyl-2-pyrazolines. Eur J Med Chem 36(60):539-543

27. Rajendra Prasad Y, Lakshmana Rao A, Prasoona L, Murali K, Ravikumar P (2005) Synthesis and antidepressant activity of some 1,3,5-triphenyl-2pyrazolines and 3-(2/1-hydroxynaphthalene-1-1/-yl)-1,5-diphenyl-2pyrazolines. Bioorg Med Chem Lett 15(22):5030-5034

28. Zhao PL, Wang F, Zhang MZ, Liu ZM, Huang W, Yang GF (2008) Synthesis, fungicidal and insecticidal activities of $\beta$-methoxyacrylate containing $\mathrm{N}$-acetyl pyrazoline derivatives. J Agric Food Chem 56(22):10767-10773

29. Kini S, Gandhi AM (2008) Novel 2-pyrazoline derivatives as potential antibacterial and antifungal agents. Indian J Pharm Sci 70(1):105-108

30. Siddiqui AA, Rahman MA, Shaharyar M, Mishra R (2010) Synthesis and anticonvulsant activity of some substituted 3,5-diphenyl-2-pyrazoline-1carboxamide derivatives. Chem Sci J 1:1-10

31. Gowramma B, Jubie S, Kalirajan R, Gomathy S, Elango K (2009) Synthesis, anticancer activity of some 1-(Bis N, N-(Chloroethyl)-amino acetyl)-3,5disubstituted 1,2-pyrazolines. Int J Pharm Tech Res 1(2):347-352

32. Klimova El, Maartnez Garca M, Klimova Berestneva T, Alvarez Toledano C, Alferdo Toskano R, Ruz Ramres L (1999) The structure of bicyclic ferrocenylmethylene substituted 2-pyrazolines and their reactions with azodicarboxylic acid N-phenylimide. J Org Metal Chem 585(1):106-114

33. Padmavathi V, Sumathi RP, Chandrasekar Babu N, Bhaskar D (1999) 1,3-Dipolar cycloaddition of dipolar reagents to bifunctional olefins in the presence of chloramine-T (CAT). J Chem Res (S):610-611

34. Soni N, Pande K, Kalsi R, Gupta TK, Parmar SS, Barthwal JP (1987) Inhibition of rat brain monoamine oxidase and succinic dehydrogenase by anticonvulsant pyrazolines 56(1):129-132

35. Ferigolo M, Barros HM, Marquardt AR, Tannhauser M (1998) Comparison of behavioral effects of moclobemide and deprenyl during forced swimming Pharmacol Biochem Behav 60(2):431-437

36. Palaskaa E, Aytemira M, Uzbay IT, Erola D (2001) Synthesis and antidepressant activities of some 3,5-diphenyl-2-pyrazolines. Eur J Med Chem 36:539-543

37. Shader RIMD, Greenblatt DJMD (1999) The reappearance of a monamine oxidase inhibitor (isocarboxazid). J Clin Psychopharm 19(2):106-106

38. Guelfi JD, Strub N, Loft H (2000) Efficacy of intravenous citalopram compared with oral citalopram for severe depression. Safety and efficacy data from a double-blind, double-dummy trial. J Affect Disord 58(3):201-209

39. Gopalakrishnan M, Sureshkumar P, Kanagarajan V, Thanusu J (2005) Aluminium metal powder (atomized) catalyzed Friedel-Crafts acylation in solvent-free conditions: a facile and rapid synthesis of aryl ketones under microwave irradiation. Catal Commun 6(12):753-756

40. Gopalakrishnan M, Sureshkumar P, Kanagarajan V (2007) Easy to execute one pot synthesis of 1,2,4,5-tetrazines catalyzed by activated fly-ash. J Korean Chem Soc 51(6):520-525

41. Thirunarayanan $G$ (2011) Solvent free synthesis, spectral studies and antioxidant activities of some 6-substituted $\omega$-bromo-2-naphthyl ketones and their esters. Indian J Chem 50B(4):593-604

42. Thirunarayanan G, Mayavel P, Thirumurthy K (2012) Fly-ash: $\mathrm{H}_{2} \mathrm{SO}_{4}$ catalyzed solvent free efficient synthesis of some aryl chalcones under microwave irradiation. Spectrochem Acta 91A:18-22

43. Thirunarayanan G, Mayavael P, Thirumurthy K (2011) National conference on recent trends in green synthesis (RTGS-2011). Alagappa University, Karaikudi, 5-6 August

doi:10.1186/2191-2858-2-20

Cite this article as: Sasikala et al.: Eco-friendly synthesis and antimicrobial activities of some 1-phenyl-3(5-bromothiophen-2-yl)-5(substituted phenyl)-2-pyrazolines. Organic and Medicinal Chemistry Letters 2012 2:20.

\section{Submit your manuscript to a SpringerOpen ${ }^{\odot}$ journal and benefit from:}

- Convenient online submission

- Rigorous peer review

- Immediate publication on acceptance

- Open access: articles freely available online

- High visibility within the field

- Retaining the copyright to your article

Submit your next manuscript at $\gg$ springeropen.com 